\title{
7 The vision of integrated (missional) existence in Rom 12-15
}

Romans 12.1-2 is the overture to Rom 12.3-15.13: it introduces and frames the way of life described in Rom 12.3-15.13. ${ }^{1}$ In this chapter we will, first, sketch how our novel explanation of Paul's use of reason language in Rom 12.1 emphasises a new aspect in how Rom 12.1-2 frames Rom 12-15. Second, we will consider several passages in Rom 12-15 in which Paul uses language or ideas that resonate with the elements we have used in our explanation (an emphasis on vocation, on a new kind of thinking, on genuine humanness, and on sign production $^{2}$ ).

This will require, for the first part, a discussion of the form and function of Rom 12-15, of how this material is framed by Rom 12.1-2, and of how interpreters attempt to integrate it with the rest of the letter (section 7.1), before we present our own proposal (section 7.2). In the second part, we will look at resonances in Rom 12-13 (section 7.3) and Rom 14-15 (section 7.4).

\subsection{The form and function of Rom 12-15}

Rom 12.1 marks a major shift in Paul's argument, opening a new section, with a different character from the preceding argument.

1 Most interpreters agree on this point, with varying metaphors: Schnelle 2014 calls Rom 12.1-2 the "Überschrift des ethischen Hauptabschnitts" with a "leserlenkende Funktion" which defines a "Bezugsrahmen" in which to understand the statements that follow (606); for Seidensticker 1954 it is the "Motto für den folgenden Pflichtenkatalog" (256); for Wolter 2019 it is a "Präambel" (243); for Matera 2010, the "foundation for all that follows" (284); for Hahn 2017, the "preface to the pastoral counsel that follows" (212). Cf. further examples by Reichert 2001, 228; Jewett 2007, 724. An exception is Evans 1979, 33.

2 That is "actions performed in order to signify, embody and express the meaning of the Christ event” (see section 1.4).

Ә OpenAccess. () 2021 Simon Dürr, published by De Gruyter. (cc) BY-NC-ND This work is licensed under the Creative Commons Attribution-NonCommercial-NoDerivatives 4.0 International License. 


\subsubsection{Paraenesis?}

This judgment rests on observations about the form of Rom 12-15, which is often described as paraenesis. ${ }^{3}$ Dibelius' characterisation has been influential: "einzelne Mahnungen, oft in Spruchform, lose aneinandergehängt, oder unverbunden nebeneinander stehend." ${ }^{4}$ Dibelius further maintained that such rules or instructions as one finds in Rom 12-13 are not formulated for a specific occasion, but meet general needs of the early Christians; they are said to have "nicht aktuelle, sondern usuelle Bedeutung." 5 The function of paraenesis is generally agreed to be advice about matters of which those who are addressed are already convinced $^{6}$ and thus the content is often conventional or traditional; in addition the material is often expected to be arranged in random fashion. ${ }^{7}$ Sometimes such form critical observations have corresponded with a relative lack of interest in Pauline ethics. ${ }^{8}$

\subsubsection{Integration of "theology" and "ethics"?}

While for Dibelius the ethical instructions were unconnected to the main exposition of the letter, for many scholars since it was vital to find some way of integrating Rom 1-11 and Rom 12-15. The relation between Rom 1-11 and Rom 12-15 has been described in various terms: as "theology followed by application", ${ }^{9}$ or as a turn from "theological exposition" to "pastoral exhortation", ${ }^{10}$ or from the "indicative" to the "imperative."

Many scholars since claim that, for Paul, "theology" and "ethics" belong together and attempt to integrate them in some way. Thus, for instance, Dunn

3 Dibelius 1919, 71 (for Rom 12-13). Cf. for example Betz 1988, 215; Byrne 1996, 361; Matera 2010, 283. Wolter 2019, 245 n. 9 maintains the usefulness of the term against the criticism of Esler 2003, 53. On paraenesis, see also the contributions in Starr and Engberg-Pedersen 2005.

4 Dibelius 1919, 70.

5 Dibelius 1919, 70. Some interpreters have distinguished between "Allgemeine Paränese” in Rom 12.3-13.14 and "Spezielle Paränese” in Rom 14.1-15.13 (e.g. Käsemann 1980, 311).

6 Matera 2010, 283.

7 Thompson 2011, 10 summarises Dibelius' concept of paraenesis as "unconnected ethical advice.”

8 Cf. Dunn 1998, 628 n. 10.

9 Cf. Dunn 1998, 626 (though he finds the distinction "misleading").

10 Hahn 2017, 211.

11 Bird 2016, 411, recalling the widely used schema established by Bultmann 1924. The distinction is now often criticised as inadequate (cf. the literature in Schnelle 2014, 597 n. 4). 
maintains that Paul's "theology was a living theology, a practical theology through and through", such that the "application is inherent in the exposition itself" and the "imperative is the inevitable outworking of the indicative"; ${ }^{12}$ for Matera, "Paul is the herald of a gospel in which theological and ethical issues are so closely related that it is difficult for the apostle to proclaim this gospel without pointing to its ethical implications,"13 and the goal of Rom 12.1-15.13 is to show that the gospel is the "source of moral life." ${ }^{14}$ For Schnelle, transformation and participation in Christ are categories in which divine action and the human action can be integrated such that ethics becomes "die Entsprechung zum neuen Sein." 15 However, such claims do not yet show how such an integration works and how it relates to concepts in the ancient encyclopedia. ${ }^{16}$

\subsubsection{More than ethical advice?}

To explain how such an integration might work, it is necessary to find a function for the actions which Rom 12 describes, which goes beyond mere "ethics" in the sense of right moral conduct. One such model is Wolter's correlation between "ethos" and "identity". ${ }^{17}$ Any social group which wants to maintain its distinctive identity needs a distinctive ethos which displays its identity. Thus it is the function of such an ethos,

es den Angehörigen der Gruppe möglich zu machen, sowohl ihre Zusammengehörigkeit als auch ihre Unterscheidung von der Mehrheitsgesellschaft zur Darstellung zu bringen und damit die Gruppe erkennbar werden zu lassen und die soziale Kohäsion unter ihren Mitgliedern zu befestigen. ${ }^{18}$

Applying this model to Romans, Wolter suggests that Rom 1-11 can be read as a “Konzeptualisierung der christlichen Identität” and Rom 12,1-15.13 as a sketch, in several spheres of action, of “ethisch[e] Verhaltensweisen” in which Paul's

12 Dunn 1998, 626, 630.

13 Matera 2010, 161.

14 Similarly, Thompson 2011, 120 sees Rom 12.1-15.13 as indication of "Paul's concern for moral transformation".

15 Schnelle 2014, 597, 599-600. He even claims a "selbstverständliche Einheit von Glauben und Handeln in der Kraft des Geistes" (610).

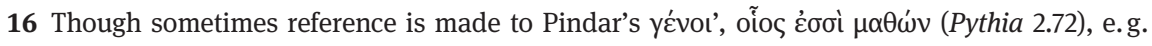
Dunn 1998, 630.

17 Cf. Wolter 2009; Wolter 2019, 244.

18 Wolter 2019, 244. 
hearers can express ("zum Ausdruck bringen") this new identity, such that it becomes "erfahrbar" for group-members and "erkennbar" for outsiders. ${ }^{19}$ Wolter also hints at the function of Rom 12.1-2 as providing a "theologisch-ethische Deutung" for what follows. ${ }^{20}$ The advantage of the model is that "ethical" actions are more than merely right moral conduct: they have the function of displaying an identity. The problem, however, is that this function only appears to a sociological perspective on Paul's community formation processes and is not related to concepts Paul himself might use, as part of the ancient encyclopedia. In his Romans commentary, Dunn had already hinted at a similar model, when he applied the categories of his version of a "New Perspective on Paul" to Rom 12:

In the letter so far Paul's chief concern has been to redefine the relation between Jew and Gentile within the saving purpose of the one creator God. And that has involved a redrawing of the boundaries and redefining of the characteristics which mark out the people of God. Since ethics and communal relationships were part of these boundaries and distinctive characteristics, his task cannot be completed unless he carries on the process of redefinition into the sphere of ethics. ${ }^{21}$

Dunn's account seems to relate the function of the ethical actions as identity markers for the redefined people of God more directly to the theological exposition in the preceding letter than Wolter's does, but this may also be because his reading of the soteriology in the "theological exposition" of the letter sets great store by sociological categories. The integration is still one that appears only on the horizon of the interpreter. ${ }^{22}$

As a final model that emphasises a function of the concrete practice to which Rom 12-15 exhorts which goes beyond mere "ethics”, we will consider Barclay's reading of Rom 12.1-15.13 as being about the "construction of a Christian habitus". ${ }^{23}$ Because the concept of a habitus implies dispositions, valuations, and perceptions in a given culture that are embodied, ${ }^{24}$ this perspective on the "ethical instruction" sees certain actions, relations, and attitudes as expressive of

19 Wolter 2019, 244.

20 Wolter 2019, 243.

21 Dunn 1988b, 716.

22 Or if it is presented as part of the ancient encyclopedia, then in very general terms, unrelated to the text of Romans, e.g.: "for a Jew it would be self-evident that faith and theology must come to expression in daily living" (Dunn 1988b, 708).

23 Barclay 2015, 493-519, here 493. For Barclay's retrieval of Bourdieu's concept of habitus, see Barclay 2015, 506-8, especially n. 23-25.

24 Cf. Barclay 2015, 507. 
values, and thus again as more than merely "right conduct". It allows Barclay to interpret the language about the $\sigma \tilde{\omega} \mu \alpha$ in Rom 6.12-13 and 12.1 in terms of what is enacted in the body. ${ }^{25}$ Some of his formulations seem very close to our own articulation in terms of sign production, for instance, when he says that for Paul "the body is the place where the resurrection life of Jesus (the new self) becomes visible and active in human lives", that the "renewal of the mind" (Rom 12.2) needs to be "expressed in the "presentation of the body" (12.1), or that "it is in the body that the believer ... is required, visibly and demonstrably, to display the presence of the resurrection of Christ, in the service to righteousness and holiness." 26 Barclay is also right in emphasising that Paul is concerned with "the formation of a community structured by and oriented to the good news." 27 What Barclay has in mind here are in particular criteria of worth, status, honour, and cultural distinctions which are part of the surrounding culture, but which have no place in the new community which is to be based on "unconditioned welcome", and aims for a "way of life recalibrated in disregard of whatever ethnic, social, or individual characteristics had previously constituted the believer's cultural or symbolic capital."28 The strength of this approach is that the community is supposed to express in their habitus a new orientation of values which correspond to the good news. Barclay can also bring into correspondence his interpretation of Paul's theology of grace, as marked by incongruity with the worth of the human recipient, with the values that the embodied habitus should reflect, namely a "welcome" irrespective of criteria of worth, "ignoring norms or identities extraneous to the good news." ${ }^{29}$ At the same time, the logic of gifts which create obligations allows Barclay to claim a concept from the ancient cultural encyclopedia as underlying the nexus between the human response and God's action in Christ. ${ }^{30}$ Finally, Barclay can frame this nexus in terms of an el-

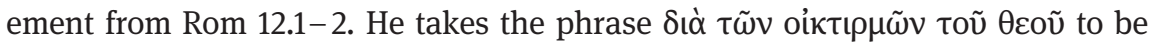
the foundation of the act of presenting one's body, and that this appeal is to the mercies of God "which bears no relation to the preceding status." 31

We have discussed Barclay's reading in some detail, because it is an excellent example for how an account of Paul's "theology" and his "ethics" could be integrated, based on concepts that are part of the cultural encyclopedia (gifts),

25 Barclay 2015, 504-505.

26 Barclay 2015, 505.

27 Barclay 2015, 508.

28 Barclay 2015, 509.

29 Barclay 2015, 512.

30 Cf. Barclay 2015, 505.

31 Barclay 2015, 508. 
and because "ethical" actions appear as expressive of something, and not merely as "right moral conduct". Our own explanation is in many formal respects similar. However, we also have some reservations with regards to Barclay's account. First, Barclay seems to put too much emphasis on "values" and "dispositions", and not enough on the "missional" aspects of the new behaviour. ${ }^{32}$ Second, while he claims that "God wills newly competent agents who express in practice their freedom from sin and slavery to righteousness", ${ }^{33}$ in his reading of Paul, incongruity is perfected to such an extent that human agency still seems to get less scope than it perhaps should ("what is given them is not a new set of competencies added to their previous capacities" ${ }^{34}$ ). The main differences, however, will emerge from our own positive proposal.

\subsection{How Rom 12.1-2 frames Rom 12-15}

In this section we show how our own explanation of Paul's use of reason language in Rom 12.1 emphasises a new aspect in how Rom 12.1-2 frames 12.3-15.13. To show this we will (1) argue that Paul uses the paraenetic material to depict his vision of community life in Rom 12-15; (2) summarise our reading of Rom 12.1-2; (3) propose a way in which our reading of Rom 12.1-2 frames Rom $12-15$.

\subsubsection{Paraenesis to depict a vision of community life}

We propose that Paul is using the literary form and the traditional content of "paraenetic" materials not in order to add a practical application to his exposition (like a modern sermon), but rather because in this way he can paint a picture of the kind of community with whose formation he is concerned..$^{35}$

This then serves as the concrete picture of community life which is required for the missional collaboration which Paul seeks to promote. Our own assump-

32 For our use of "missional”, cf. section 1.4.

33 Barclay 2015, 519.

34 Barclay 2015, 518.

35 Insofar as Paul encourages to a way of life which his hearers have not yet adopted, one should speak of a protreptic function; insofar as he encourages them in something they already share, of a paraenetic function. Our proposal is not, however, about the literary genre of Romans as such (cf. for instance Aune 1991). 
tion on the "reasons for Romans" debate ${ }^{36}$ is that Paul writes his letter to the Romans in order to win the Christ-followers in Rome for a friendly collaboration in his missional project. ${ }^{37}$ Because this missional project requires a certain kind of community life and a particular understanding of the good news and its implications, Paul sets out his basic understanding of the good news in the body of the letter. But because this missional project requires a missional existence of the communities, he is at the same time using the letter to encourage them to the life which embodies such a missional existence, in appropriate sign production.

That paraenetic material serves such a function, in which a vision of more than "ethical" advice is offered, is strongly confirmed by the way in which this material is framed in Rom 12.1-2. To make this point clear, we will first summarise our reading of Rom 12.1-2.

\subsubsection{Summary of our reading of Rom 12.1-2}

In chapter 6, we have offered our own explanation of Paul's use of reason language in Rom 12.1 as a contribution to reading Rom 12.1-2. Romans 12.1-2 functions as a protreptic appeal to a certain way of living in the communities of

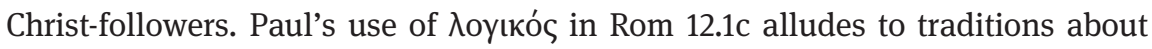
genuine humanness, the role of human beings in the cosmos, and the exercise of reason as their specific capacity. It presents the way of living to which Paul exhorts as the fulfilment of the genuinely human vocation (and indirectly as the fulfilment of the aspiration of the philosophers).

36 Cf. Donfried and Manson 1977, Wedderburn 1988, Jervis 1991, Theobald 2001, Reichert 2001. See the further literature cited by Barclay 2015, 455 n. 13. Since a full explanation of Paul's reason language in Rom 12.1, given its place in the structure of the letter, depends in part upon what Paul hopes to achieve in writing his letter as a whole, it is necessary here to state our assumption, even though there is no space to argue our point in detail. Our interpretation is similar to the emphasis on community formation in Barclay 2015, 455-457; cf. Theobald 2001, 14: "[Paulus] wollte die Römer für eine ehrliche apostolische Partnerschaft mit ihm dadurch gewinnen, dass er sie von seiner Sache überzeugte".

37 Jewett 2007, 726 speaks of "Paul's missionary project" but restricts it too narrowly to Paul's plans for Spain. Reichert's proposal - that Paul wants to both prepare his hearers in Rome in case he can visit them and continue in his "Missionswerk" and equip them for a "selbständige Weiterverbreitung des Evangeliums" in case he will not - has much to commend itself (cf. Reichert 2001, 99). What we mean by "missional" emerges from our reading of the human vocation in terms of sign production (cf. our remarks in section 1.4). 
We have further argued that presenting one's body as a living sacrifice (Rom 12.1b), the action to which Paul exhorts, refers to more than simply ethical living: what is in view is a missional existence, one that produces signs of the new reality which has been inaugurated in the messiah. Romans 12.1c identifies this as the genuinely human existence in which the vocation of human beings as such can be fulfilled. This is based on the liberation and renewal of human beings which Christ has brought and which now grounds the missional existence in the conditions of the new age which has been inaugurated in the death and resurrection of Jesus and become available for those who belong to him, both Jewish and Gentile Christ-followers.

We have further argued that in Rom 12.2 Paul speaks of the renewal of the mind and of the capacity to discern the concrete will of God in every situation of life in which Jesus-followers find themselves. We have circumscribed this discernment of what God wants as the concrete determination of how in a given situation Christ-followers can produce the best sign of the good news and the new creation. Such a sign will be an action which expresses the good news of Christ even in the adverse and hostile conditions of the present (cf. Rom 12.2a) and which is oriented toward the eschatological consummation in the new creation (cf. especially Rom 13.11-14). ${ }^{38}$

\subsubsection{How this reading frames Rom 12-15}

Our reading of Rom 12.1-2 implies that Paul frames the actions to which he exhorts in 12-15 as instances of the sign production in which the human vocation consists. Paul applies the concept of a human vocation, with its structure of a sign production based on an understanding of God in relation to the world, to those in Christ and to the new cosmos inaugurated in Christ. This means that the kind of actions for which Rom 12-15 gives examples are more than merely "ethical” acts. Rather, they are signs produced by newly liberated human beings which "interpret" what God has done through Christ, reflecting the new understanding of God and responding to it and embodying it appropriately and communicatively.

If our reading is on target, then Paul's allusion to the philosophical tradition about a human role in the cosmos, with its structure of grasping the truth about

38 The eschatological dimension which is implicit in Rom 12.2a becomes explicit in Rom 13.11-14. The correspondence between Rom 12.1-2 and 13.11-14 has been emphasised by Käsemann 1980, 348. 
the cosmos and producing signs of this understanding, appeals to a concept that is part of the ancient encyclopedia, and that itself already implies an integration of "theology" and "ethics". For both aspects are held together in the role of

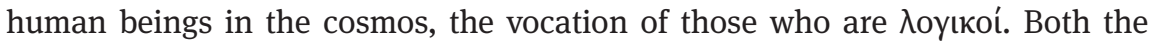
true understanding of God in relation to the cosmos and the articulations as appropriate signs - words, deeds, relations, and dispositions - are based on the

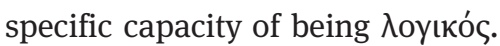

Paul applies this concept of a human vocation to those who are in Christ and have been baptised. This means there are important discontinuities with the philosophical tradition. Their bodies have been liberated from having to produce signs of "sin" and "death" and are now able to produce signs of the new reality. ${ }^{39}$ Their minds have been renewed and they are able to understand God as he has revealed himself in the Christ event. ${ }^{40}$ Their role is the role of human beings in the cosmos, but it is in dynamic relation to the inaugurated new creation and oriented towards its eventual consummation. ${ }^{41}$

But at the same time, because the structure of the human vocation is the same, what Paul claims as something which can be fulfilled in the concrete actions done by those in Christ is the fulfilment of that genuine humanness to which the philosophers aspire. ${ }^{42}$ This genuine humanness is only possible, for Paul, through what Christ has done, but in so far as they live up to it in concrete acts, it becomes a sign of their genuine human life. ${ }^{43}$ The genuine humanness displayed in such actions is itself a sign of the good news, and hence missional, because the good news implies that what Christ has done has been for the rescue

39 See section 5.3 .

40 See section 6.4 .

41 See section 5.4 .

42 This is supported by Rom 16.19, where Paul explicitly expresses his intention for his hearers: "For while your obedience is known to all, so that I rejoice over you, I want you to be wise in

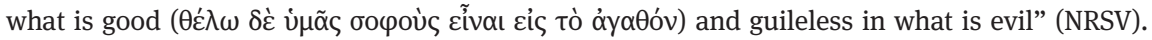
For the copious Stoic material on the figure of the wise man (ó бopóc; sapiens) see SVF $3.544-$

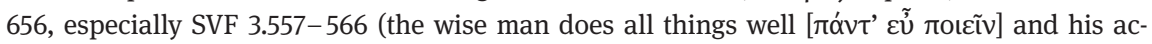

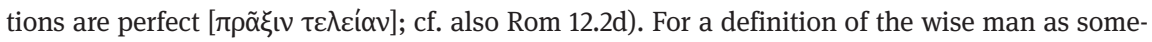
one able to speak well on the great issues and to keep the right measure ( $\mu \varepsilon \tau \rho i ́ \omega \varsigma)$ in his dealings with the vicissitudes of life, see Isocrates, Ad Nic. 39 (cf. Rom 12.3 and the emphasis on unity [see also Rom 16.17]).

43 Thus we agree with Barclay that "God's grace ... generates and grounds an active, willed conformity to the Christ-life, in which believers become, like Christ, truly human, as obedient agents" (2015, 519), but we are not sure whether his insistence on the "eccentric existence" (cf. 518, following the work of D. H. Kelsey, cf. Barclay 2015, 501 n. 12) misses out on a dimension of genuine humanness which our reading of Romans (cf. chapter 5) attributes, as one of the implications of the Christ gift, to those who are rescued. 
of human beings, not just from future "wrath", but for their liberation and restoration to their genuinely human role in the cosmos. That restoration is not a repristination, ${ }^{44}$ however, because it is the role of human beings within a cosmos in which the new creation has been inaugurated, and their sign production in the present - in suffering and prayer - can become part of God's action to bring about the new creation in its full realisation. ${ }^{45}$

Thus, the actions to which Paul exhorts are framed as missional signs. Paul is concerned with community formation, but this community formation serves the purpose of missional existence: a community which lives in the way outlined in Rom $12-15$ is itself producing a sign of the new reality. It thus becomes the primary place, in advance of the eschatological consummation, in which the "new creation" is manifesting itself in a world that is still in "eager longing" for this to become fully apparent (Rom 8.19).

The fact that much of the content of Rom $12-13$ is not materially different from what contemporaries could approve ${ }^{46}$ should not be surprising, if Paul's concern is not with "moral instruction" as such, but, rather, with inculcating a mindset that is able to understand the revelation of Christ as the basis for a missional existence, producing appropriate signs as a service to God "im Alltag der Welt" ${ }^{47}$ and as summing up in articulate worship the praise and longing of a creation which is still in "labour pains". ${ }^{48}$ This means to live in such a way as that one's actions, thought patterns, relationships, community structures, and patterns of worship are lived with the overriding concern for the appropriate sign production for the good news, within the new creation that has begun to be launched.

We may summarise how Paul's framing in Rom 12.1-2 implies that the actions to which Paul exhorts are more than merely "ethical" in six points. First, because these acts are performed by agents who are indwelt by Christ and the Spirit, these acts are, as it were, "sacramental," pointing to a reality which

44 Cf. also Rom 5.15-21, where it is clear that God is not just restoring "Adamic" humanity to an original situation. In Christ a new situation has begun, which fulfils yet goes beyond what was intended for "Adam." Cf. also our discussion in section 5.2.4.1.

45 Cf. section 5.4 .

46 For a detailed comparison of Rom 12-13 with Jewish-Hellenistic "ethical instruction" see Thompson 2011. For other contexts, see Schnelle 2014, 610. Sometimes, however, such comparisons neglect vital differences that arise due to the embedding of actions in a way of life (for such a type of critique, cf. Rowe 2016). Of course, the eschatological outlook of Rom 13.11-14, for instance, is very different.

47 For the phrase cf. Käsemann 1970, though we use it without his implication that Paul seeks to abolish the concept of cult itself, which seems to owe much to his own context.

48 For the formulation, cf. Wright 2013, 1509. 
they also make present..$^{49}$ Second, because they are performed by subjects who are aware of a new kind of understanding. ${ }^{50}$ Third, because they are done in a liberated body, which is no longer coerced by "sin" and "death". ${ }^{51}$ Fourth, because they are done in the context of a new kind of community. ${ }^{52}$ Fifth, because they are done in obedience to the form the human task now takes (as Paul thinks, if our reading of Rom 12.1 is on target). Sixth, because they are now "missional", in the sense that others can be drawn to the message of reconciliation when they see these actions.

This way of reading the contribution of Paul's reason language in Rom 12.1 to how Rom 12.1-2 frames Rom 12-15 fully coheres with Paul's overall aims in writing the letter: ${ }^{53}$ by framing his vision of their life together as a missional existence, which fulfils the genuinely human role in the cosmos, he commends and promotes a conception of their community life which is both required for the desired collaboration in his missional project and rooted in his theological understanding of the new way of being human in Christ, to which such existence aims to witness.

\subsection{The ideal of a community fulfilling the human calling (Rom 12.1-13.14)}

In this section we consider several examples from Paul's portrait, in Rom 12.3-13.14, of the community of Christ-followers and how they should live to fulfil their human calling. The language of 入оуıкós in Rom 12.1 points to the role of

49 This seems to be in part what Barclay 2015 emphasises in statements such as "Christian life is an impossible newness given as an unfitting gift, such that everything in this life refers back to its source and foundation in the Christ-gift, and forward to its eschatological fulfilment as eternal life” (517). Cf. also Schnelle 2014, 602.

50 This would be similar to the Stoic idea that a completely right action requires right insight (cf. e.g. SVF 3.501). Cf. also Schnelle's claim that Paul's ethics is a "Einsichtsethik" or that "nicht im Materialgehalt seiner Weisungen setzt Paulus neue Akzente, sondern in der Begründung" $(2014,610)$, though it is not entirely clear what "Begründung" here means.

51 Cf. our reading of Rom 5 and 6 in chapter 5.

52 Which includes Jewish and Gentile Jesus-followers and cuts across social divides. Indifference to previous categories of worth is clearly important for such a new community, but our emphasis is that this displays a new way of being human, rather than simply a critical stance towards entrenched systems of honour. The positions discussed in section 7.1.3 can be seen as concerned with this aspect, without, however, seeing the importance of the calling of the community as such.

53 We have hinted at our assumption in sections 5.6 and 7.2.1. 
human beings within the cosmos. It puts an emphasis on genuine humanness, on understanding and the exercise of reason, and on humans discovering their place in the cosmos. Paul applies these ideas to the new reality of those in Christ.

These themes are to some extent reflected in the structure of Rom 12.1-13.14. For Paul, new creation is already at work in the "microcosm" of the community and each member must discover their place within it: They are to think clearly to discern their place and their different tasks within the "body" (Rom 12.3-8). Yet Paul expands the frame: they must also discern their place in their relations and towards outsiders (the wider world) (Rom 12.9-21) and negotiate their location in relation to the wider political reality (Rom 13.1-7). However, their overall place in the cosmos is oriented towards the eschatological horizon of new creation (Rom 13.11-14).

We have argued that Rom 12.1-2 frames the material in Rom 12-15 in terms of genuine humanness, the human vocation, sign production for the new creation, and a new kind of thinking. We will now look at examples within Rom 12.3-13.14, where Paul's portrait resonates with these themes directly: in Rom 12.3-8, with thinking and vocation (section 7.3.1); at certain points in Rom 12.9-21, with genuine humanness, thinking, and sign production (section 7.3.2); in Rom 13.11-14, with a vocational sign production for the new creation (section 7.3.3).

\subsubsection{The many tasks within the one body (Rom 12.3-8)}

Having spoken of the human calling based on the human endowment with rea-

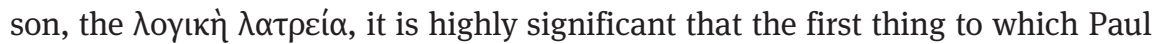

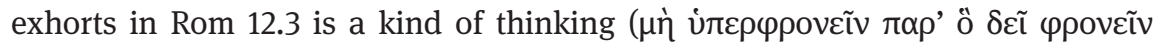

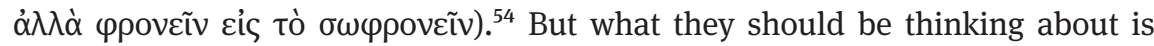
that they are one body in Christ, ${ }^{55}$ that, within this larger whole, each one of them has a different task entrusted to them, and that they should not be thinking

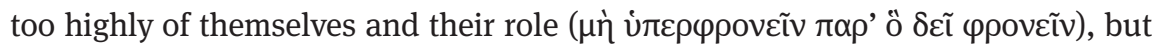
with appropriate moderation assess their own role ( $\sigma \omega \varphi \rho o v \varepsilon \tilde{v})$ according the

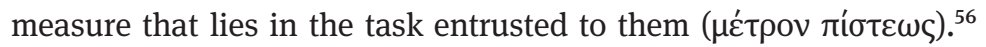

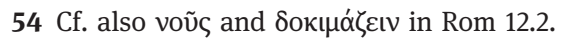

55 This point is noted by Keener 2016, 167-172 (who also connects it to reconciliation between Jews and Gentiles [170]).

56 For such a reading of $\mu \varepsilon ́ \tau \rho o v ~ \pi i ́ \sigma \tau \varepsilon \omega \varsigma$, cf. Goodrich 2012, 2013b ( clay 2015, 510 ("role of communal responsibility"); Wolter 2019, 265-266. The main argument is 
Thus, right at the start of this passage, Paul puts an emphasis on thinking as the human proprium required for genuine humanness, but now oriented towards one's place within the "body" of Christ. Paul addresses every individual in the

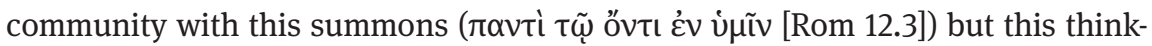
ing occurs in the context of the community. ${ }^{57}$

Furthermore, by rightly discerning their place within this larger whole, they are also oriented towards the new kind of service, the missional existence of the community. Paul expresses this vocational point with the simile of a human body $(\sigma \tilde{\omega} \mu \alpha)$ and its members $(\mu \varepsilon \dot{\varepsilon} \lambda) .{ }^{58}$ All the members of the "body" have a dif-

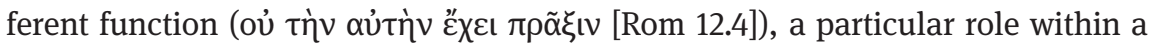
larger whole, which need to work together for the purpose of the whole. All those in Christ (Rom 12.5) have a common vocation - the missional existence of the community - but this overall vocation requires different functions, or, as they

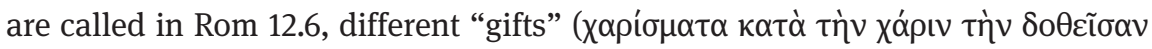
$\grave{\eta} \mu \tilde{\imath} v \delta ı ́ \alpha \varphi \rho \alpha)$.

Based on these two observations, we can conclude that Rom 12.3-8 confirms our reading of the $\lambda$ оуєкं $\lambda \alpha \tau \rho \varepsilon i \alpha$ as referring to the genuine human vocation, in resonance with the philosophical traditions we have studied. Three observations are noteworthy in this regard.

First, the picture of organic unity of the community in which each member contributes to the purpose of the whole is decidedly "teleological." This coheres well with the entire providential and teleological background of the Epictetus parallels we have studied in chapter 4.

Second, the focus on a common task of the community also resonates with the themes of the larger discourse on being human and how the endowment with reason is what enables humans to fulfil their specifically human goal. We may point back to our discussion, in section 3.1.8, of Aristotle's Politics, where

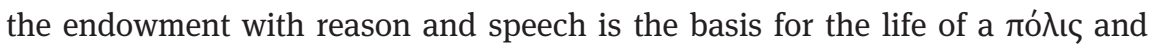
for the justice required for such a life together. The community of those in Christ has become possible through the Christ event; they have been liberated and re-

the contextual coherence achieved for Rom 12.3-8 and the correspondence with 2 Cor 10.13. Cf.

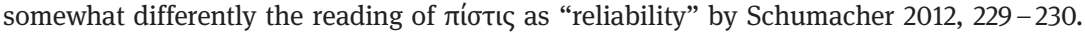

57 So, rightly, Keener 2016, 168. Cf. Phil 2.1-5.

58 The story of the application of this image in the political sphere, from Menenius Agrippa onwards, has been told many times. See the material in Walter 2001. For Stoic uses of this image see in particular Thorsteinsson 2006, 151-2 (including Epictetus 2.10.4). Epictetus 2.10.4 (see sec-

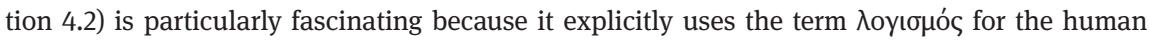
capacity for reason and applies it to the members (hand or foot) with regards to thinking and acting with reference to the whole. 
newed in their thinking, and now they can and should think clearly in the way required for the life and purpose of the community.

Third, the differentiation, from a basic human role, into more specific circumstances and adapted to personal characteristics also finds parallels in Greco-Roman philosophical contexts. We have discussed this aspect with regards to Epictetus 3.23 and 2.10 in section 4.2 (where we also referred to Panaetius' teaching about the four personae in Cicero's De officiis). In this perspective, Rom 12.3 also fits with the emphasis on self-knowledge required to fulfil one's role. ${ }^{59}$

Hence, the parallels which we have emphasised for the interpretation or Rom 12.1 are also fruitful parallels for Rom 12.3-8. To summarise how Rom 12.3-8 contributes in our reading to the missional vocation: the point is to be embedded within a particular (messianic) community and to exercise one's function within it in service of the common mission in a way that most promotes the common sign production for the gospel. This requires sound estimation of one's own role and individual gifts.

\subsubsection{Signs of genuine humanness and the relation to others (Rom 12.9-21)}

In Rom 12.9-21, Paul continues his portrait of the ideal life of the community but already broadens the focus towards outsiders (cf. Rom 12.14, 12.17-21). The passage is headed by a statement about genuine love (Rom 12.9a) which introduces a leitmotif developed in Rom 13.8-10 as a central mark of the life of those in Christ. $^{60}$ The short statements which follow (Rom 12.9b-13) paint in rapid strokes a picture of genuine humanness, in which participles (and adjectives) characterise the subjects in terms of ideal actions and dispositions. ${ }^{61}$ This looks like a counter-portrait to the list that characterises the corrupted humanity of Rom

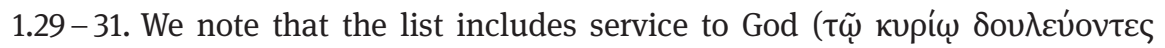
[Rom 12.11]). ${ }^{62}$

59 Cf. Epictetus 2.10.1 and 1.6.25, discussed in chapter 4.

60 Against Thorsteinsson 2010, 96, who finds the reference to love "actually quite peripheral".

61 For a similar determination of the function of the participles, cf. Reichert 2001, 260.

62 Thus even though in a sense Rom 12 as a whole is under the heading of the service to God performed by Christ-followers, this particular statement expresses it concretely as well. This reading is to be preferred to the textual variant $\kappa \alpha \iota \omega$ for Rom 12.11. 
The actions in view in 12.9-15 are more concrete examples of the new life in the community. ${ }^{63}$ While some statements are very basic and general (e.g. $\alpha$ ro-

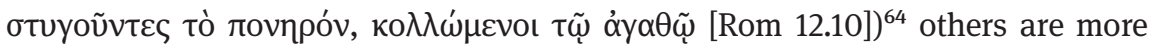

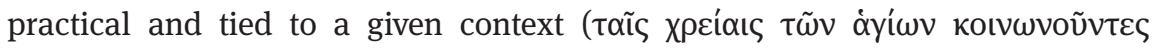
[Rom 12.13]). But they are all signs of genuine humanness. The ethos described through these actions is not missional in the sense that these have to be direct acts of proclamation: it includes statements about members getting along and

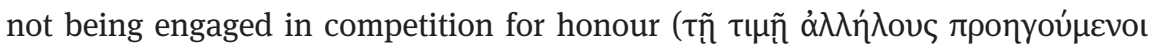
[Rom 12.10]). But it is missional in the sense that by behaving in these genuine human ways, they are producing signs which witness to the truth that a new way of being human has become possible in Christ. ${ }^{65}$ This is further supported by the observation that some of the thematic combinations seem to recall earlier statements from the letter. ${ }^{66}$

In this portrait of what the genuine human vocation looks like, it is once more significant that Paul includes a statement about the right kind of thinking ( role within the community and their contribution to its unity, and about their role and their position towards the wider world.

And this clear thinking once more has to do with their missional vocation, as becomes clear in Rom 12.17b: For they are to be minded towards the noble and

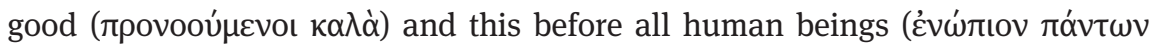
$\alpha \nu \theta \rho \omega ́ \pi \omega v) .{ }^{67}$ This supports our reading in terms of sign production, because what they are thinking about should express itself in actions which others perceive (and hence is missional).

And since Rom 12.17b stands in parallel to the injunction not to repay evil for

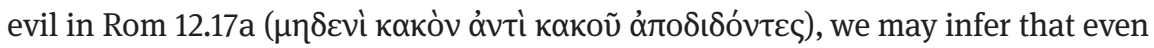
the statements about not taking revenge (Rom 12.19-21) have in view the purpose of the community's existence, namely being a witness to what the good news proclaims, the new creation inaugurated in Christ, and producing the ap-

63 While Rom 12.14 looks towards outsiders, it may still refer to what should be done when the community meets. This verse is often compared to Jesus tradition; for analyses, see Wilson 1991, 165-171; Thompson 1991, 96-105; Jacobi 2015, 87, 92-96; cf. Wolter 2019, 290.

64 Note how this is taken up again, forming a kind of inclusio, in Rom 12.21. Though there, additionally, it emphasises the injunction not to take revenge.

65 Cf. Rom 12.17.

66 For example Rom 12.12 recalls Rom 5.2-5, which already reflects the new situation in Christ (cf. section 5.1).

67 Cf. also Phil 4.8. Note also the motif of $\pi \rho o v o i ́ \alpha$ as one of the marks of being human (cf. Dierauer 1977, 227-229). 
propriate signs of genuine humanness. As far as possible, they should live in peace with all human beings (Rom 12.18), and display genuine humanness in this way. But if this is not possible, it is precisely their reactions to hostility which can function as signs faithfully produced for the new reality of which they are called to be witnesses. Paul has already explained in Rom 8.22-23 that - within the eschatological horizon he presupposes - this may involve suffering.

Thus we conclude that Rom 12.9-21 resonates at certain points directly with an emphasis on a genuine human vocation, on clear thinking in service of this vocation, and on producing signs which reflect the new reality which has begun in Christ.

\subsubsection{Rom 13.11-14: The human vocation in its eschatological horizon}

Romans 13.11-14 places the human calling into its eschatological horizon. ${ }^{68}$ Thus it explains in more detail what not being "conformed to the present age" (Rom 12.2a) means and how the "renewal of the mind" (Rom 12.2b) relates to the new creation. ${ }^{69}$ The human calling has the structure of a sign production based on understanding. We can see this structure also in Rom 13.11-14, with an emphasis on eschatology: (1) The aspect of understanding that Paul emphasises in Rom 13.11-12b is the discernment of the eschatological moment, the Christ-followers' location with regards to the renewal of creation. (2) Paul exhorts to a sign production based upon this understanding in Rom 13.12c-14. The connection between the right understanding and the actions which reflect it can be seen most clearly in the language used in Rom 13.12cd, which recalls both earlier statements which we have argued should be understood as describing a sign production (in Rom 12.1b [see section 6.2] and in Rom 6.12-23 [see section 5.3.2.2]); but it can also be seen in the language used in Rom 13.14, which makes it likely that also Rom 13.13 should be understood in this way. The following remarks substantiate this argumentative outline.

Ad (1): Paul emphasises the discernment of the eschatological moment in

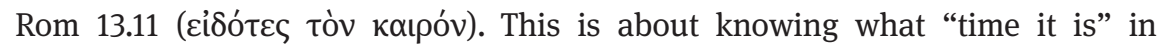

\footnotetext{
68 Cf. the significant parallels of our passage with 1 Thess 5.1-11, which is full of similar eschatological motifs, and culminates with a vocational statement (5.10) and an encouragement to unity (5.11).

69 For links between Rom 12.2 and Rom 13.11-14, cf. e. g. Cranfield 1979, 679; Byrne 1996, 327 (though he seems to restrict the function of the eschatological reference to motivation); Hahn 2017, 237.
} 
terms of the new creation inaugurated in the Christ event and its soon expected

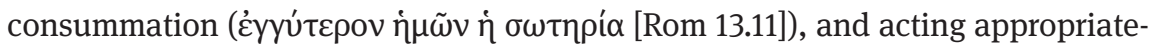
ly ("waking up" [Rom 13.11]) based on the recognition of the moment. The $\sigma \omega \tau \eta$ pí $\alpha$ in Rom 13.11 refers not just to the rescue from divine wrath, but to the moment when creation will be fully transformed to the new creation and humans transformed and embodied within it. ${ }^{70}$

Paul uses the imagery of night and day to express the eschatological "location" of those in Christ in Rom 13.12ab: The night (vù ) has advanced (it is coming

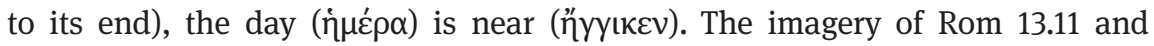
13.12ab mesh together (cf. the image of $\varepsilon y \varepsilon \rho \theta \tilde{\eta} v \alpha \mathrm{l})$ : the approaching dawn is that of the near $\sigma \omega \tau \eta$ í $^{\alpha}$ (Rom 13.11), including the fully transformed new creation.

Ad (2): The two exhortations in Rom 13.12cd make use of the eschatological imagery that Paul has set up in Rom 13.12ab:

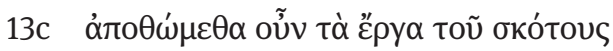

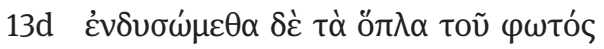

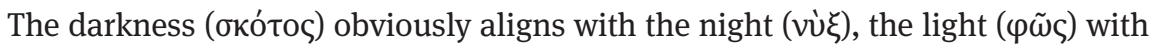
the day (í $\left.\mu \varepsilon^{\prime} \alpha\right)$, in their eschatological valence as set up by Paul's language. Paul uses these terms to qualify the actions to which he exhorts and thereby makes a connection between these actions and what they signify and embody

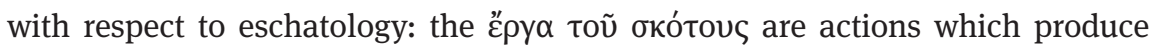

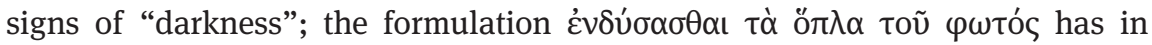
view actions which produce signs of "light" (though the actions are referred to metonymically ${ }^{71}$ ). Thus Rom $13.13 \mathrm{c}$ and $13.13 \mathrm{~d}$ are clear instances of sign production.

This is supported by the observation that these exhortations are similar to the exhortations in Rom 12.1b and Rom 6.13, 6.16, 6.19, which use $\pi \alpha \rho i ́ \sigma \alpha v \alpha$ language in different ways to speak about sign production, as we have argued in sections 6.2 and 5.3.2.2. This similarity is most apparent in the overlap of the

70 Cf. our discussion of Rom 8.17-30 (section 5.4.2). Through Christ and the Spirit the transformation of those in Christ has already begun; this incipient renewal is the condition for their ability to produce signs in the present, which God can use in "producing" the new world (cf. 1 Cor 15.58).

71 The formulation refers to the "putting on" rather than the "using" of the "weapons". But the

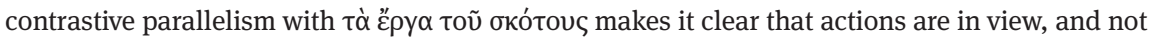
just an "identity". Jewett's assumption (2007, 822-823) that ö $\pi \lambda \alpha$ here must refer to "armour" instead of "weapons" is unnecessary. 


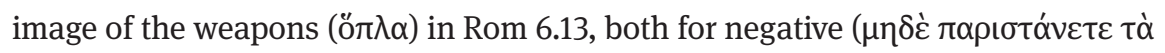

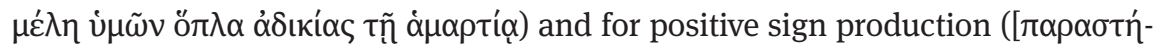

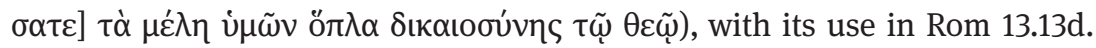

Thus, we may conclude that Rom 13.12 describes the sign production of those in Christ in the present as pointing to the new creation. The genuine human vocation in the eschatological present consists of actions which are both signs of the new creation and which embody it in the present.

A reading of Rom 13.12 in terms of sign production is also supported by

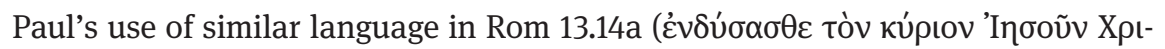

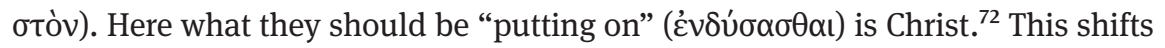
the emphasis to another way of describing the sign production of the community: the actions to which they are exhorted are pointing to Christ, they witness to the Christ event and its significance. Because Christ is the one in whose death and resurrection a new age has been inaugurated, this formulation still belongs to the eschatological horizon. It also points to Christ as the one who is genuinely human and through whom they can exercise their genuinely human vocation.

Our interpretation of Rom 13.12 and 13.14 makes it likely, that also Rom 13.13 should be understood to be drawing a connection between "ethical" action in the present and what it implies in terms of eschatological understanding. While Paul's language in Rom 13.13 sounds just like a description of decency

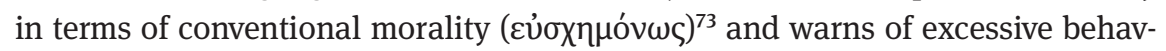
iour which any moralist might want to rule out, the eschatological valence of the day and light imagery established in Rom 13.11-12b gives Paul's language of $\dot{\omega} \varsigma$

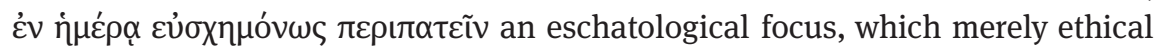
applications of day and night imagery would lack. ${ }^{74}$

They are not to engage in bouts of drinking and revelry and strife and so on (Rom 13.13) because they would thereby behave just as when they could not do otherwise, being beholden to the desires of the body, and producing signs of the rule of "sin" (cf. Rom 6.12). Their behaviour would be producing signs of the "night" from which they are already liberated, even as the entire cosmos has

72 For comparative material on this image cf. Wolter 2019, 343-344. Our reading in terms of sign production has the advantage of integrating this language with Paul's other statements and bringing out the active, missional and vocational emphasis which includes, but goes beyond Wolter's reading of the image (344).

73 Cf. e.g. Dunn 1988b, 788; Byrne 1996, 400.

74 An example for the latter would be Seneca, Ep. 122. 
not yet been transformed to the light of "day" which their sign production is to anticipate and embody in the present. ${ }^{75}$

Hence, we may conclude from the above remarks that Rom 13.11-14 clarifies the human vocation in terms of eschatology and in relation to Christ. The shape of the human calling in Paul is to discern what God is doing in relation to the world and to be part of a community which produces the signs shaped by that understanding and embodying it appropriately (ethos) and communicatively (mission). Given that for Paul and early Christ-followers, the Christ event and what it inaugurates is the decisive action of God in the present, fulfilling the human calling requires this eschatological understanding and the appropriate reflection of it, both in distance from the world beholden to the "darkness" (Rom 13.12c, cf. Rom 12.2a) and in being "armed" and fully equipped with the weapons of "light" (13.12d). By producing signs which appropriately reflect the meaning of the Christ event, their semiotic sphere of action becomes charged with the meaning of who Christ is. Christ is the truly human one who has brought about the change of conditions which can release the genuinely human life, the life that fulfils the human calling (Rom 5.12-21). Romans 13.11-14 confirms that genuine humanness means living in such a way as to embody who Christ is and what he did for the world and the new creation which he has inaugurated in appropriate and intelligent action, as sign production of and for the new creation.

Thus, we conclude that Rom 13.11-14 resonates with Rom 12.1-2 and with how it frames the material in Rom 12-13. It amplifies the eschatological notes of new creation which are hinted at in Rom 12.2 and makes explicit how the genuinely human vocation is Christ-shaped (which was only implicit in Rom 12.1b via its reference to Rom 6). The new humanity is marked in particular by Christ and the new creation, and thus their actions in the present are not merely "ethical” but vocational signs of an integrated missional existence.

\subsection{Signs of the kingdom and the united community: Rom 14.1-15.13}

Further direct resonances with our explanation of Rom 12.1-2 in terms of sign production and vocation can be found in Rom 14.1-15.13. In this section we

75 Likewise, the contrast between "putting on" Christ (Rom 13.14a) and not providing for the flesh and its desires (Rom 13.14b) does not suggest that the former merely refers to ethical behaviour; rather it makes it likely that providing for the flesh and its desires amounts to a failure to be genuinely human in the way that it is now possible: by producing with one's actions signs of the liberation, through Christ, of the body from its enslavement to desires. 
argue in outline that in Rom 14.1-15.13 Paul explains (1) a meta-principle which is (2) vital for the unity of the community of those in Christ. (3) The unity of the community is itself the ultimate sign of the genuine humanness that has become possible in Christ: when Jews and Gentiles glorify God together, they fulfil their vocation as the new humanity.

Romans 14.1-15.13 confirms our reading of Rom 12.1 in terms of a human vocation and of sign production at several points. For the meta-principle is itself explained in terms of vocation and sign production.

Most scholars assume that Paul speaks in Rom 14.1-15.6 about a situation in Rome, where the labels "weak" and "strong” refer to actual groups (and hence that Paul "addresses real [not hypothetical] problems in the Roman congrega-

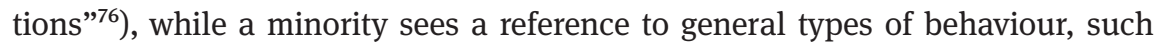
as Paul might have encountered in various places. ${ }^{77}$ Scholars have offered widely diverging proposals on the identification of the "strong" and the "weak": ${ }^{78}$ a majority see the "strong" as predominantly Gentile Christ-followers (but including Jews like Paul) and the weak as predominantly Jewish Christ-followers (though including proselytes and God-fearers). ${ }^{79}$ Others have seen the "weak" as Gentile Christ-followers, who as former God-fearers are still influenced by Jewish customs, ${ }^{80}$ or the "weak" as Jews who are not Jesus-followers and the "strong" as Jews who are, ${ }^{81}$ or have associated the labels with status differences among Christ-followers in Rome. ${ }^{82}$ For our own reading, it is not necessary to determine the extent to which Paul's exposition in Rom 14.1-15.13 is specific to the situation in Rome, nor to identify the precise contours of the groups or types of behaviour that are in view. This is because the resonances with our reading of Rom 12.1-2 in terms of vocation and sign production are at the level of how Paul argues, and do not directly depend on a reconstruction of a social or historical situation. However, we concur with the majority view that Paul's language

76 Barclay 2015, 511.

77 E. g. Stowers 1994, 320 (“dispositions of character”); Reichert 2001, 271-275 (the "weak" is a "Typus, der ... noch nicht durch konkrete Personen repräsentiert ist” [271]); Thorsteinsson 2010, 91-92; cf. Wolter 2019, 348.

78 For a concise overview see Wolter 2019, 347-348.

79 Cf. Wolter 2019, 347.

80 E. g. Schmithals 1988, 492 (who lists a lot of comparative material on "wine" and "meat" consumption [491-492]).

81 So Nanos 1996, 85-165 (criticised by Reasoner 1999, 131-136).

82 So Reasoner 1999. 
fits best with a social context in which there are different views on the observance of Jewish food laws and Sabbaths. ${ }^{83}$

For our first point, then, we note the following. In 14.1-15.13 Paul addresses in initially ${ }^{84}$ somewhat veiled terms a problem that has been a central point of contention throughout his ministry, namely the problem of aspects of Jewish ethos which can no longer be maintained in the same way as before for all those who now belong to a community in which Gentile Jesus-followers are accepted without having to become Jewish. Paul tries to explain a meta-principle and he chooses the practice of abstaining from meat (expressed as eating vegetables [Rom 14.2]) as a concrete example to illustrate this principle. ${ }^{85}$

The principle concerns cases where there are different convictions about particular actions (e.g. eating or not eating meat) among different Christ-followers. When two Christ-followers come to opposite stances regarding such a question, their stance may also imply a judgment about the other and about how the other lives as a Christ-follower. Paul urges them not to despise or judge the other based on their stance but to accept one another ${ }^{86}$ based on their having been accepted

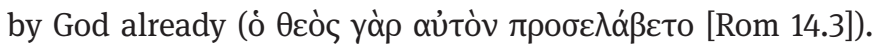

Significantly for our reading, Paul argues for this acceptance of the other based on the vocation of the other. For the acceptance by God is based upon what Christ has done, so that they belong to him, and upon this a new service is founded. ${ }^{87}$ Thus, when discussing potential tensions in the community, he reaches precisely for the category of vocational service. In Rom 14.4, Paul proceeds to argue by using metaphors for vocation: who are you to judge the

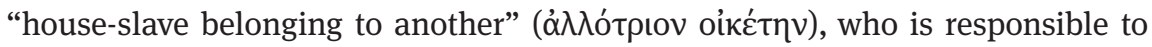
their own master (kúpıs). ${ }^{88}$ It is also confirmed by the vocational language of not living or dying for one-self, ${ }^{89}$ but to the kúpıos in Rom 14.7-8. Thus, Paul

83 Barclay 2015, 511 claims a "now widespread consensus" regarding this point, which he elaborates in Barclay 2011.

84 It is made explicit in Rom 15.8-9.

85 That a generalisation is in view can be seen from the fact that Rom 14.5 mentions a different practice (relating the observation of special days). Cf. also Rom 14.21 (drinking wine).

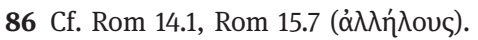

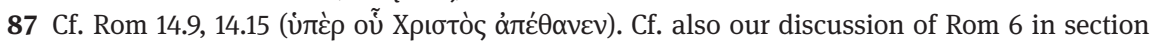
5.3.

88 Cf. also Rom 14.12 (using $\lambda$ óyos but not in a sense relevant for Rom 12.1). For slaves as property of their masters see Bradley 2011, 242 (slaves as "items of property over which their owners had complete powers of disposal”). Further, Nasrallah 2019, 57-59 on the varied ontological status implied in such perceptions. Paul's point here is that no one else but the кúpıoৎ has a right to judge the service of those who belong to him.

89 For this language as vocational, cf. Rom 6.10-11. 
confirms the idea of a service to God (or perhaps here Christ) for all Christ-followers in order to stress that this does not give one Christ follower the right to judge another's service to God..$^{90}$

Furthermore, Paul's explanation of this acceptance can be illuminated by our notion of sign production. Paul can let certain differences of conviction and different vocational judgments stand (Rom 14.5) because the overriding principle is that their actions should be producing the appropriate signs in which their vocation consists. In some cases, they may perform or not perform a particular action, but what matters is that their doing or not doing so produce an appropriate sign:

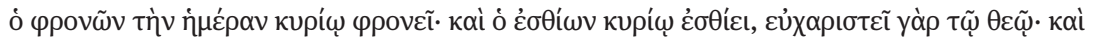

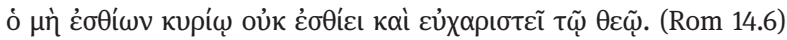

This leads us to our second point. ${ }^{91}$ Such thinking is required for the unity of the community because it is able to overcome differences of opinion by adopting a viewpoint which sees actions and decisions not merely as acts, but in terms of sign production in which what signifies and what is signified matter, and in some cases what is signified matters more. ${ }^{92}$

What an action signifies depends on circumstances, which include the convictions of fellow Christ-followers. An act which produces a sign of one's own conviction may be an appropriate sign in some circumstances. But insofar as it creates a stumbling block for the "brother", is to be judged a wrong act, precisely because of the sign it produces (Rom 14.13). ${ }^{93}$ Even if it is a good conviction in itself, ${ }^{94}$ insofar as it harms a "brother", it is no longer a "walking in love" (oủ-

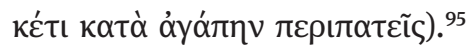

90 Cf. also the self-examination with regards to one's role in the "body" in Rom 12.3-8. This point holds at least in matters that do not pass a certain threshold (thus Paul uses the example of $\lambda \alpha \alpha_{\alpha} \alpha v \alpha$ ). If the point would be circumcision, we should rather expect the intense polemics of Philippians 3.2-3.

91 Beginning from Rom 14.13, Paul focuses on how the principle of acceptance is important for unity.

92 The same principle is expressed in 1 Cor 10.31 (Elı

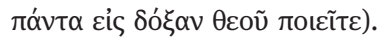

93 Paul plays with different uses of kpíveıv in Rom 14.13.

94 Cf. the reference to the good spoken of as evil (Rom 14.16). The meta-stance Paul takes is also the basis for the statement in Rom 14.14, which points to a logic of sign production as well: insofar as something becomes, in context, a sign of what is kotvóv, it may no longer be appropriate as a sign to be produced by the agent who wants to serve Christ, even if their personal conviction is different. The discussion in 1 Corinthians $10.23-33$ is, of course, closely related. 95 And thus it deviates from the leitmotif of love (cf. Rom 12.9a, Rom 13.8-10). 
The relevance of an understanding in terms of sign production for the unity and vocation of the community is clearly confirmed by Rom 14.17-18. The particular questions of food and drink are not the issue in and of themselves, ${ }^{96}$ but insofar as they become the occasion for an appropriate sign production in the given circumstances and given the involved agents: whether the sign concerns "brothers" in the community or even outsiders. ${ }^{97}$ What matters is the "kingdom of God" and serving in it:

17a oủ yó

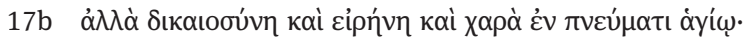

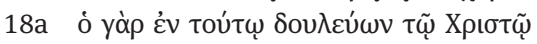

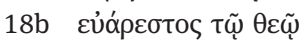

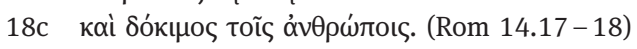

Paul here clearly states that what matters is not the particular praxis in terms of food and drink (Rom 14.17a), but whether one's actions produce an appropriate

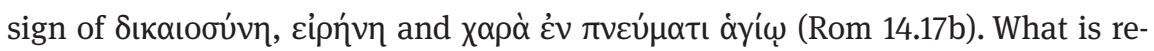

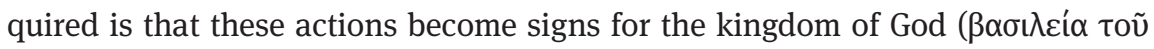

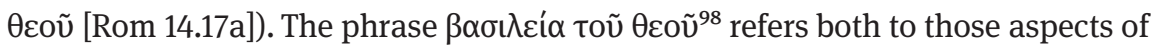
the current age in which God's reign is already inaugurated through those in

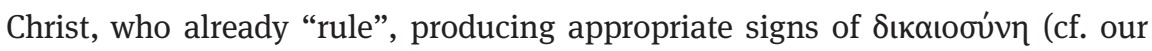
discussion of Rom 5.17 and 5.21 in section 5.1.3), and to the consummate reality in the future, the new creation to which their sign production points. The com-

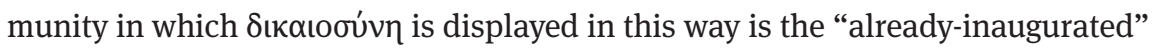
sign of the new world which has been decisively launched in Christ. ${ }^{99}$ It is in this

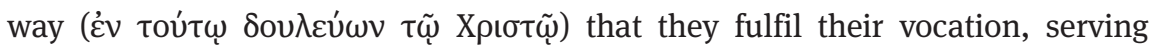
Christ (Rom 14.18a). In doing so, they produce signs and serve in a way which is well-pleasing to God (Rom 14.18b, cf. Rom 12.1, 12.2). And someone who serves

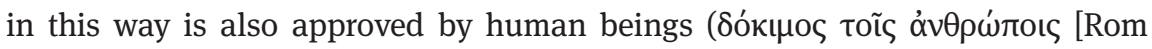
14.18c]), both other Christ-followers and those outside. ${ }^{100}$ This shows that such sign production is also missional, because it communicates a different way of being human, one which can overcome differences of ethos in service of a common calling, as the "body" of Christ.

96 For a perspective in which humans go beyond sustenance, see also Epictetus 1.6.14.

97 The perspective on outsiders may be implicit in the subject of Rom $14.16(\beta \lambda \alpha \sigma \varphi \eta \mu \varepsilon i ́ \sigma \theta \omega)$. It

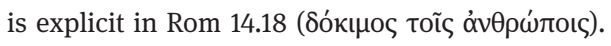

98 Cf. 1 Cor 4.20; 6.10-11; 15.24; 15.50; Gal 5.21; 1 Thess 2.12.

99 Cf. Rom 5.17 and 5.21.

100 Even though outsiders might also react differently, with incomprehension or even persecution. 
This leads us to our third point. The unity in the "body" is itself the ultimate sign for the kingdom and the new way of being human. Paul stresses the importance of this unity in Rom 14.19, where what counts is the building up of the com-

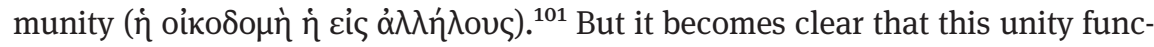
tions as a sign of what God is doing, when, in Rom 14.20, Paul calls the united community itself tò हैpyov toṽ $\theta \varepsilon o v ̃$ which would be undermined by human actions insisting on divisions based on "food". ${ }^{102}$ The sign of unity is at the same time God's work and something to which the appropriate vocational sign production of those who belong to the community contributes (which requires clear thinking about one's own convictions, and the differing convictions of other members in the "body").

This point is articulated particularly clearly towards the end of our passage, in Rom 15.5-7. Paul articulates the goal of a united community in the form of a wish that expresses what he has been trying to promote with his writing: ${ }^{103}$

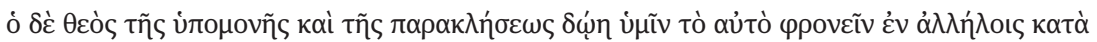
Xpıбтòv 'Inбoũv (Rom 15.5).

This picks up exactly Rom 12.1-2 by expanding upon the kind of unity in the

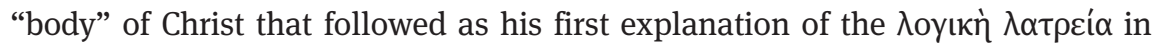
Rom 12.3-8. They need unity in the kind of thinking ( their vocational purpose, defined by Christ, so that they can produce the appropriate signs which fulfil their genuinely human calling:

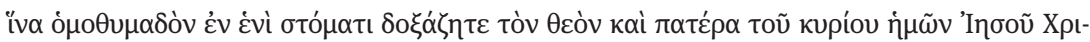
бтоบ̃ (Rom 15.6).

Their calling is to praise God, together, as a united community, in which Jews and Gentiles who belong to the messiah, Jesus, can stand together as a renewed

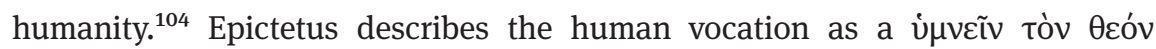

101 Cf. also Rom 15.2.

102 Barclay 2015, 512, 515 seems to restrict the reference of the "work of God" to a "person", rather than the community (like e.g. Cranfield 1979, 723). In contrast to Rom 14.15, however, the context of Rom 14.19 and the overall trajectory towards the unity expressed in Rom 15.5-7 seems to favour an interpretation in terms of the community (so e.g. Dunn 1988b, 825;

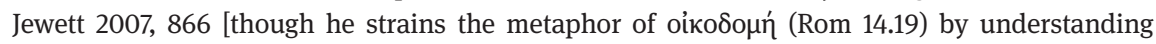
हैpyov as "building erected by God"]). Note that Epictetus 1.6.19 offers a fascinating vocational parallel to the ع́pyov toũ $\theta \varepsilon o \tilde{~ i n ~ R o m ~ 14.20 . ~}$

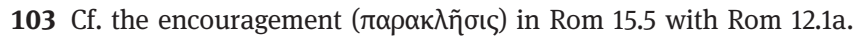

104 This becomes explicit in Rom 15.8-9. 
(1.16.20), such as God can be known in his providential works. Paul describes the

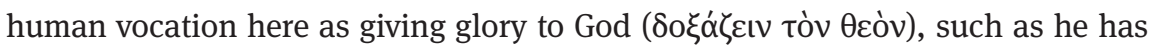
made himself known in the messiah. And when they do this together, as Jewish and Gentile Christ-followers, with one mind and with one voice, their worship proclaims in words what their unity communicates as the ultimate sign of the new way of being genuinely human, which has become possible through the rescue brought in Christ: the true humanness of the Jew-plus-Gentile community created in the risen Christ and by the Spirit. ${ }^{105}$ This is what underlies Paul's appeal for mutual welcome:

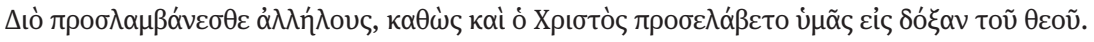
(Rom 15.7)

They should accept one another, as Christ has accepted them, and in this way

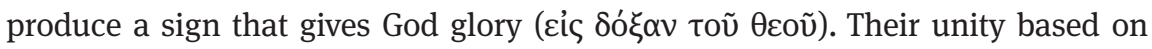

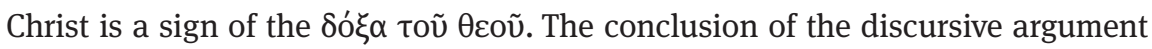
of the letter, Rom 15.7-13, brings these themes to a climax, in a complex tapestry which weaves together scriptural texts - law, prophets, writings - with a focus on the messiah and the renewed humanity in which Jews and Gentiles (Rom 15.8-9) can be brought together in the messianic communities, in their common worship and in their joint service.

\subsection{Conclusion}

In this chapter, we have shown that our novel explanation of Paul's reason language in Rom 12.1 emphasises a new aspect in how Rom 12.1-2 frames Rom 12-15. By applying the idea of a human vocation - with its structure of a sign production based on a new understanding of God - to the task of those in Christ, Paul frames the "ethical" material and the actions to which he exhorts as a missional sign production in which the human vocation is fulfilled. In framing Rom 12-15 in this way, "theology" and "ethics" are integrated by a conception that is part of the ancient encyclopedia. This is because the structure of the human vocation as a sign production based on an understanding of God in relation to the world already integrates in itself "theology" and "ethics”. Paul's application of the idea to those in Christ goes beyond anything Epictetus might have envisaged, because such existence is oriented towards Christ and the new creation. However, because the structure of the human vocation is the same, he might have still

105 Cf. also how Ephesians 2.11-21 develops such ideas explicitly. 
recognised, had he come across Paul's letter, that Paul claimed in this genuinely human existence the fulfilment of the aspirations of the philosophers.

Furthermore, we have pointed out resonances in Rom 12-15 with these themes from Rom 12.1-2. Thus, we have seen that the integrated missional existence which is offered in an idealised picture in Rom 12-15, despite using conventional forms, nevertheless contains a strong emphasis on the vocation of Christ-followers to represent God and witness to the good news by their deeds and words. We have also pointed out how the logic of sign production, with which we have analysed the structure of the human calling in Paul, and in the philosophical tradition, is an influential part of the picture offered in Rom 12-15. The goal of the united community, which represents the fulfilment of genuine humanness, is to overcome the divide between Jews and Gentiles, by co-relating them to Christ, in mutual appreciation, common worship and joint service to God. Paul hopes that his writing will prepare a future collaboration in the matter of the good news with the Christ-followers in Rome. He draws on powerful protreptic motifs that are familiar from philosophical discourse and which are influential in the wider cultural contexts. But these are ultimately rooted in his theological anthropology, which, we have argued, is centrally determined by the idea of a vocation for human beings. It is in the shape of this vocation that what is separated out as theology and ethics, or theory and praxis, is inseparably linked and bound together. The notion of sign production further emphasises how this is grounded in the defining characteristic for human beings in Paul's time: their endowment with reason. This reason has been renewed in the wake of the Christ event, and the renewed human beings can now aspire to embody and communicate the truth of the good news in a way that anticipates the new creation and thus contributes to its eventual consummation. 